\title{
Spatial Variability and Relationship of Mangrove Soil Organic Matter to Organic Carbon
}

\author{
Pasicha Chaikaew ${ }^{1}$ and Suchana Chavanich ${ }^{2}$ \\ ${ }^{1}$ Department of Environmental Science, Faculty of Science, Chulalongkorn University, Bangkok, Thailand \\ ${ }^{2}$ Department of Marine Science, Faculty of Science, Chulalongkorn University, Bangkok, Thailand \\ Correspondence should be addressed to Pasicha Chaikaew; pasicha.c@chula.ac.th
}

Received 11 June 2016; Revised 3 November 2016; Accepted 29 November 2016; Published 29 January 2017

Academic Editor: Teodoro M. Miano

Copyright ( 2017 Pasicha Chaikaew and Suchana Chavanich. This is an open access article distributed under the Creative Commons Attribution License, which permits unrestricted use, distribution, and reproduction in any medium, provided the original work is properly cited.

\begin{abstract}
Degradation and destruction of mangrove forests in many regions have resulted in the alteration of carbon cycling. Objectives of this study were established to answer the question regarding how much soil organic carbon (SOC) is stored in wetland soils in part of the upper northeastern Gulf of Thailand and to what extent SOC is related to organic matter (OM). A total of 29 soil samples were collected in October 2015. Soil physiochemical analyses followed the standard protocol. Spatial distributions were estimated by a kriging method. Linear regression and coefficient were used to determine the suitable conversion factor for mangrove soils. The results showed that surface soil $(0-5 \mathrm{~cm})$ contained higher SOC content as compared to subsurface soil $(5-10 \mathrm{~cm})$. Considering a depth of $10 \mathrm{~cm}$, this area had a high potential to sequester carbon with a mean \pm standard deviation of $5.59 \pm 2.24 \%$. The spatial variability of $\mathrm{OM}$ and SOC revealed that organic matter and carbon decreased with the distance from upstream areas toward the gulf. Based on the assumption that $\mathrm{OM}$ is $50 \%$ SOC, the conversion factor of 2 is recommended for more accuracy rather than the conventional factor of 1.724 .
\end{abstract}

\section{Introduction}

Since the Industrial Revolution, there has been a speedy increase in atmospheric carbon dioxide $\left(\mathrm{CO}_{2}\right)$ concentration. Global levels of $\mathrm{CO}_{2}$ already passed above $400 \mathrm{ppm}$ mark in 2015 [1]. The natural movement of carbon across the atmosphere, vegetation, soils, and the oceans is the key to mitigate climate change due to elevated $\mathrm{CO}_{2}$. Globally, soils store more carbon, about 3.3 times, than the atmosphere and 4.5 times the bionic pool [2]. Among different ecosystems, wetlands often represent the largest carbon pool because of their anoxic conditions and thus play a vital role in carbon cycles. Of the $1,500 \mathrm{Pg} \mathrm{C}$ stored in the Earth's soils, peat-forming wetlands are estimated to contain about 300-600 Pg C [3]. Southeast Asian peatlands account for the most important carbon sink, representing $68.5 \mathrm{PgC}$ or $77 \%$ of global tropical peatlands [4]. Despite accounting for the importance of wetlands to ecosystems and humans, one-third of global wetlands have been lost due to land use change, aquaculture inversion, and wetland degradation. Carbon emissions from mangrove loss are uncertain, but it is estimated that about $10 \%$ of all carbon emissions are released by deforestation worldwide [5]. Thailand alone is estimated to have lost approximately $82 \%$ of its wetlands [6]. Chonburi Province, Thailand, also has experienced wetland loss as a result of urban sprawl, industrial development, and deforestation. Between 1961 and 2007 , its wetland coverage was reduced from $38.2 \mathrm{~km}^{2}$ to $7.8 \mathrm{~km}^{2}$, or by about $80 \%$ [7]. Wetland conversion directly affects the size of the soil carbon pool.

Soil organic carbon (SOC) is part of the carbon stored in soil organic matter (OM). The estimation of SOC has followed various techniques from the oldest to the simplest method. The assumption that OM contains 58\% carbon was first established by Sprengel in 1826 [8]. Since then, the conversion factor of 1.724 has been repeatedly used as a rough estimate of organic carbon content for universal applications. Other early studies published in German scientific literature assumed that OM holds 58\% carbon (conversion factor of $1.724)[9,10]$ and $60 \%$ carbon (conversion factor of 1.667) [11, 12]. However, these numbers are considered too low in many 
areas. The application of 1.9 and 2.5 was recommended to convert OM to SOC for soils in the top and subsurface layers, respectively, worldwide [13]. Soil type and environment result in SOC-to-OM variations. In wetland ecosystems, a factor of 1.842 has been determined for most peats [14], 1.88 (advocated 2) for peat in Wales [15], and 2.07 and 2.34 for wetlands in England [16,17]. A recent study has claimed that a factor of 2, based on the assumption that OM is 50\% carbon, is more accurate in almost all cases than the conventional factor of 1.724 [18].

Soil management can manipulate the balance of carbon sink and source processes. When OM is broken down, some of the SOC can be quickly mineralized and converted to $\mathrm{CO}_{2}$. Carbon thus disappears from the soil. The high amount of soil organic matter tends to be limited to the soil surface, probably at a depth of 5 to $10 \mathrm{~cm}$ [19]. Organic matter often binds to fine particles, particularly clay, and the binding processes further prevent soil carbon loss [20]. The study of SOC and its relationship to OM is important; yet there are research gaps to be filled regarding mangrove soils in Thailand. It is still questionable how much SOC is stored in the wetland soils and to what extent SOC is related to OM. The aim of this study is to spatially investigate the SOC content in mangrove areas at surface and subsurface layers, as well as the association of SOC-to-OM conversion. The result of the conversion factor from this study is useful for estimating either SOC or OM in similar environments. The specific objectives of this study are threefold:

(1) Investigating the concentrations of SOC in surface soil $(0-5 \mathrm{~cm})$ and subsurface soil $(5-10 \mathrm{~cm})$.

(2) Assessing spatially explicit OM and SOC contents (0$10 \mathrm{~cm}$ ).

(3) Identifying the conversional function between OM and SOC in mangrove soils $(0-10 \mathrm{~cm})$.

\section{Materials and Methods}

2.1. Site Description. Estuarine mangrove forests along the coast of the Gulf of Thailand are influenced by the opencoastal environment during high tide and fresh water flow during low tide. The study area is part of the Nature Education Center for Mangrove Conservation and Ecotourism located in Chonburi Province $\left(13^{\circ} 20^{\prime} 37.05^{\prime \prime} \mathrm{N}, 100^{\circ} 56^{\prime} 34.83^{\prime \prime} \mathrm{E}\right)$ on the eastern coast of the Gulf of Thailand. The center was established in 2001 for mangrove conservation and education purposes. The conservation area covers approximately $480,000 \mathrm{~m}^{2}$, but the focus area of interest is limited to the area within and around the wooden walkway due to the constraints of area accessibility. The area within the walkway covers $113,240 \mathrm{~m}^{2}$ and extends to $220,000 \mathrm{~m}^{2}$ for the study area. The water channel receives runoff from residential communities and industries upstream and then drains through the mangrove conservation area before being discharged into the Gulf of Thailand. Chonburi has a tropical savanna climate [21] and temperatures rise in April, with the average daily maximum at $35.2^{\circ} \mathrm{C}\left(95.4^{\circ} \mathrm{F}\right)$. The monsoon season, May through October, has heavy rain and somewhat cooler temperatures during the daytime but nights remain warm. Rich variations of fauna such as mud skipper, flying fox, fiddler crab, sesarma mederi, oyster, cockle, banana shrimp, and snake are commonly found. The main mangrove dominance is Avicennia alba $\mathrm{Bl}$. due to their adaptive characteristics in tolerating a saline environment. Other plant species found across the conservation area include Rhizophora apiculata Blume, Rhizophora mucronata, Sonneratia griffithii, Sonneratia alba, Xylocarpus granatum, and Xylocarpus moluccensis. The presence of poor mangrove growth was near the entrance of the walkway and appears in the southeast center of the study area.

2.2. Sampling Design. The sampling site was marked by a handheld GPS (Garmin GPSMAP ${ }^{\circledR} 62 \mathrm{sc}$ model) on site. The boundary of the area was mapped using Google Earth imaginary layout [22]. The geographic coordinate system used was WGS84 before being projected to the UTM_Zone_47N system for consistent data analysis. The spatial sampling sites were planned on the grid-based sampling design with a cell size of $80 \mathrm{~m} \times 80 \mathrm{~m}$. From an initial grid design providing 35 soil samples covering the entire area, a total of 29 soil samples from the surface $(0-10 \mathrm{~cm})$ across the study area were available for analysis due to limited accessibility (Figure 1). Soil samples were collected in October 2015. All the samples were collected during low tides; thus a hand collection technique was implemented. To collect samples, a $10 \times 5 \mathrm{~cm}^{2}$ soil core was used from each designated location within a square grid. The collected sediments were cut into two layers: surface $(0-5 \mathrm{~cm})$ and subsurface $(5-10 \mathrm{~cm})$. All samples were kept at $4^{\circ} \mathrm{C}$ at the sampling moisture content for laboratory processing.

2.3. Analysis of Soil Characteristics. The physiochemical sediment properties, that is, texture, $\mathrm{pH}$, salinity, electrical conductivity (EC), total dissolved solid (TDS), and soil texture, were analyzed. After air-dried samples were prepared, the percentages of sand, silt, and clay in the sediments were determined by hydrometer testing [23] and then compared with a soil texture triangle to identify soil texture [24]. The ratio of soil to water was $1: 2.5$ as suggested by Jackson [25]. The measurement of $\mathrm{pH}$ was determined by a $\mathrm{pH}$ meter (Vetus, pH-009 (III), USA). Salinity, EC, and TDS were analyzed by a portable handheld EC meter (Hach, sensION 156, USA) [25].

2.4. Assessment of Organic Matter. The loss on ignition (LOI) method was employed to analyze organic matter content at a $10 \mathrm{~cm}$ depth. The wet soil samples were completely ovendried at a temperature of $105^{\circ} \mathrm{C}$ until the weight of dried soils remained constant. The dried soil samples were then burned in a furnace at $550^{\circ} \mathrm{C}$ for 4 hours before being weighed. Organic matter content was calculated from the soil sample weight before and after burning by using the following equation:

Organic matter content (\%)

$$
=\frac{\text { Oven-dried soil }(g)-\text { Burned soil }(g)}{\text { Oven-dried soil }(g)} \times 100 \text {. }
$$

2.5. Assessment of Soil Organic Carbon. The soil samples were freeze-dried overnight in a freeze dry/shell system 


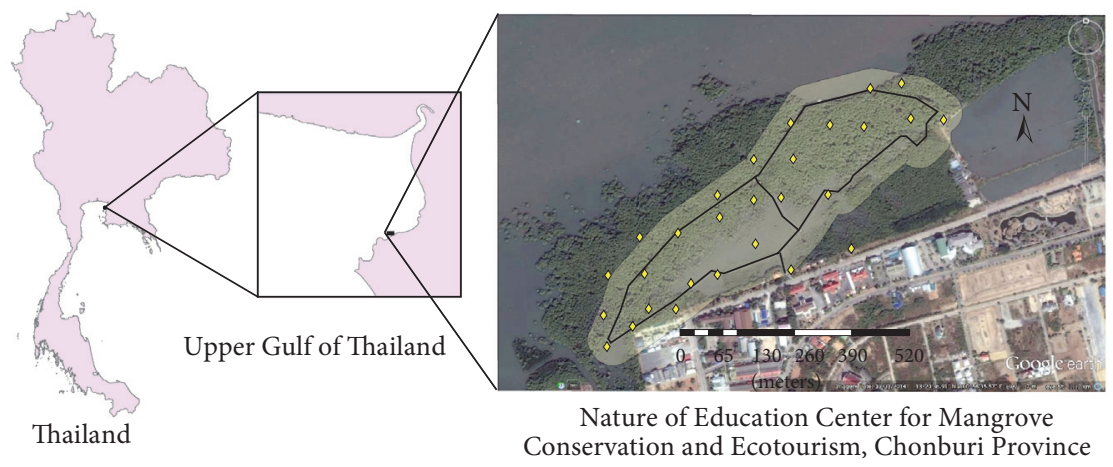

Sources: Royal Thai survey department, $1: 50.000$ Google Earth. (December 31, 2014). Chonburi Province. (Accessed April 7, 2015).

$\diamond \quad$ Soil sampling sites

Trail

$50 \mathrm{~m}$ buffer

Figure 1: The Nature Education Center for Mangrove Conservation and Ecotourism located in coastal western Chonburi Province, Thailand.

(FreeZone6, Labconco, USA) and then ground to a fine powder. The fractions passing a $2-\mathrm{mm}$ sieve were stored in a polypropylene centrifuge tube. Total carbon (TC) and soil inorganic carbon (SIC) were measured by the Shimadzu gas analyzer (TOC-V $\mathrm{CPH}$ ) using separate gas analysis procedures. The $\mathrm{CO}_{2}$ evolution using tiny ball-milled samples with gas combustion was applied at different temperatures. The temperature was set at $900^{\circ} \mathrm{C}$ for the combustion process to measure TC, while adding phosphoric acid $\left(\mathrm{H}_{3} \mathrm{PO}\right)$ reaction and setting the temperature at $200^{\circ} \mathrm{C}$ to measure IC $[26,27]$. The organic carbon can then be derived by subtracting SIC from TC.

2.6. Statistical and Geostatistical Analyses. Descriptive statistics were performed to establish physiochemical properties information using SPSS 22.0. An ordinary kriging approach was used to estimate the spatial SOC distributions in both surface and subsurface layers. Three main steps in the kriging included (1) exploring measured data to characterize spatial continuity, (2) developing a semivariogram model for investigating spatial autocorrelation, and (3) estimating unknown values based on optimized weighted averages of defined neighboring locations [28]. The relationship between $\mathrm{OM}$ and SOC was carried out by a Pearson's correlation coefficient and a simple linear regression in $R$ statistical software (version 3.2.0).

\section{Results}

3.1. Soil Organic Carbon and Physiochemical Characteristics at $0-5 \mathrm{~cm}$ and 5-10 $\mathrm{cm}$ Depths. Sandy clay loam covered the majority of the surface soil, followed by sandy loam and loam. On the other hand, clay texture was dominant in the subsurface soil, followed by sandy clay loam and clay loam. Low salinity with mean values of $2.04 \mathrm{ppt}$ in surface soil and $2.22 \mathrm{ppt}$ in subsurface soil was influenced by strong water inflow from the estuary to the seaside because the data collected in this study was taken during low tides. These values were consistent with average EC values of $3.66 \mathrm{mS} / \mathrm{cm}$ and $3.96 \mathrm{mS} / \mathrm{cm}$ which indicated moderately saline condition and sea water was diluted by the fresh water. Its salinity, the mixture of saline and fresh water, ranged from 1.00 to $3.52 \mathrm{ppt}$. According to the salinity classification of Levinton [29], mangrove soil in this area was considered under brackish and slightly alkaline condition with an average $\mathrm{pH}$ above 7 . Descriptive statistics of SOC content and related parameters are summarized in Table 1.

The measured values of SOC were equally alike to the amount of TC, indicating very low inorganic carbon forms in this area. The surface soil exhibited a higher SOC content than the subsurface layer. The results show that, vertically, SOC content decreased with increasing depth. The mean observation with standard deviation SOC was $3.08 \pm 1.25 \%$ and $2.51 \pm 1.47 \%$ for the surface and subsurface soils, respectively. Thus surface soils with higher productive mangroves in this area retain a greater amount of SOC input.

Local topography and soil drainage are considered important drivers in determining carbon storage. Since the mangrove area in this study was generally flat, the erosion process to transport carbon from topsoil to the bottom of the slopes was difficult. The water-logged condition in the mangrove forest could promote depositional rates and inhibit decomposition rates [30]. It can be observed that the disturbance of soil surface from tillage, dredging, or other aquaculture activities was extremely low in the conservation area compared to agricultural space. Less soil disturbance contributed to a net positive SOC storage of estuarine wetlands [31]. The different amount of carbon deposits along depths was largely influenced by vegetation. In an area with similar decomposition rates, carbon inputs greatly depend on primary productivity. This may be explained by the size of fraction SOC inputs and decomposition rates. Since a large 
TABLE 1: Descriptive statistics of total carbon, soil organic carbon, soil inorganic carbon contents, and soil characteristics in surface and subsurface soils.

\begin{tabular}{|c|c|c|c|c|c|c|c|c|}
\hline \multirow[t]{2}{*}{ Parameters } & \multicolumn{4}{|c|}{$\begin{array}{l}\text { Surface soil }(0-5 \mathrm{~cm}) \\
\qquad(n=29)\end{array}$} & \multicolumn{4}{|c|}{$\begin{array}{l}\text { Subsurface soil }(5-10 \mathrm{~cm}) \\
\qquad(n=29)\end{array}$} \\
\hline & Max & Min & Mean & $\mathrm{SD}$ & Max & Min & Mean & SD \\
\hline Total carbon (\%) & 6.20 & 0.02 & 3.09 & 1.25 & 5.08 & 0.02 & 2.53 & 1.49 \\
\hline Soil organic carbon (\%) & 6.20 & 0.02 & 3.08 & 1.25 & 5.01 & 0.02 & 2.51 & 1.47 \\
\hline Soil inorganic carbon (\%) & 0.06 & 0.00 & 0.01 & 0.02 & 0.23 & 0.00 & 0.03 & 0.05 \\
\hline $\mathrm{pH}$ & 8.01 & 6.95 & 7.38 & - & 8.12 & 7.35 & 7.81 & - \\
\hline Salinity (ppt) & 3.04 & 1.00 & 2.04 & 0.47 & 3.52 & 1.20 & 2.22 & 0.52 \\
\hline $\mathrm{EC}(\mathrm{mS} / \mathrm{cm})$ & 5.28 & 1.88 & 3.66 & 0.78 & 6.06 & 2.24 & 3.96 & 0.86 \\
\hline TDS $(\mathrm{g} / \mathrm{L})$ & 2.64 & 0.94 & 1.83 & 0.39 & 3.03 & 1.12 & 1.98 & 0.43 \\
\hline
\end{tabular}

$\mathrm{ppt}=$ parts per thousand; $\mathrm{mS} / \mathrm{cm}=$ microsiemens $/$ centimeter $; \mathrm{EC}=$ electrical conductivity; $\mathrm{TDS}=$ total dissolved solids; $\mathrm{g} / \mathrm{L}=\mathrm{grams} / \mathrm{liter}$

TABLE 2: Descriptive statistics of organic matter (OM) obtained by loss on ignition (LOI) and soil organic carbon (SOC) obtained by gas analyzation for the $0-10 \mathrm{~cm}$ layer.

\begin{tabular}{lcccccc}
\hline $\begin{array}{l}\text { Variable } \\
(n=29)\end{array}$ & Min & Max & Mean & Median & SD & Skewness \\
\hline OM (\%) & 6.14 & 17.34 & 11.12 & 11.04 & 2.23 & 0.59 \\
SOC (\%) & 2.26 & 9.80 & 5.59 & 5.98 & 2.24 & 0.15 \\
\hline
\end{tabular}

fraction comes from root turnover, the variability of root inputs is an influential factor in carbon storage [32].

3.2. Carbon Storage $(0-10 \mathrm{~cm})$. At a depth of $10 \mathrm{~cm}$, SOC varied across vegetation species and areas. The Nature Education Center for Mangrove Conservation and Ecotourism in this study, heavily dominated by Avicennia alba Bl., stored SOC at about 5.59\% and OM 11.12\%. Observed organic matter ranged from 6.14 to $17.34 \%$ with a mean \pm standard deviation of $11.12 \pm 2.23 \%$. Soil organic matter ranged from 2.26 to $9.80 \%$ with a mean \pm standard deviation of $5.59 \pm 2.24 \%$ (Table 2 ).

\subsection{Estimated Spatial Distribution of Organic Matter and Soil} Organic Carbon $(0-10 \mathrm{~cm})$. The close values between mean and median with low skewness described the normal central tendency of the data. Log transformation was not required to perform krigged estimates. The total spatial distribution of OM showed a minimum of $9.19 \%$, maximum of $12.47 \%$, and mean \pm standard deviation of $11.08 \pm 0.75 \%$. The SOC variability demonstrated a minimum of $3.32 \%$, maximum of $7.91 \%$, and mean \pm standard deviation of $5.48 \pm 1.16 \%$. The estimated OM and SOC derived by ordinary kriging are shown in Figure 2. A spherical model was applied to fit the experimental semivariograms of OM and SOC with a cell size of $3 \times 3 \mathrm{~m}^{2}$. The semivariograms of the data were found to vary between OM and SOC. Organic matter had longer correlation range $(945.84 \mathrm{~m})$ than SOC $(322.49 \mathrm{~m})$. The nugget and sill values of OM were 3.65 and 6.30, whereas nugget and sill of SOC were 2.61 and 6.34. Moderate spatial autocorrelation was found for both OM (0.58) and SOC (0.41) as indicated by the nugget-to-sill ratio. A small ratio in SOC informs the stronger spatial dependency as compared to OM. The large spatial autocorrelation range of $945.8 \mathrm{~m}$ of
OM explained the broader homogenous scale compared to a shorter range of $322.5 \mathrm{~m}$ of SOC. Organic matter and SOC showed uniform spatial patterns, with high content near the land and low content toward the Gulf of Thailand. The tidal export of organic matter tended to be impeded by the mangrove root system and forest structure. The findings designated that plant debris and riverine influx of dissolved and particulate organic matter upstream supply a substantial degree of organic loading near the upper intertidal area.

3.4. SOC-to-OM Conversion. The average SOC content of $\mathrm{OM}$ in soils at a $10-\mathrm{cm}$ depth was approximately $50 \%$. The relationship between SOC and OM is illustrated by a scatter plot with a linear conversion in Figure 3, the regression formula being

$$
\widehat{y}=0.05+0.50(x) \text {, }
$$

where $\hat{y}$ represents dried-weight soil organic carbon (\%) measured by gas combustion analysis and $x$ represents driedweight soil organic matter (\%) measured by loss on ignition method.

In Figure 3(a), the relationship between OM and SOC of soils in this study area was weak but statistically significant $\left(R^{2}=0.25, p\right.$ value $\left.<0.001\right)$ and Pearson's correlation coefficient was 0.50 for all the samples. When considering 17 samples near the ocean (Figure 3(b)), a model was moderately fitted with statistical significance $\left(R^{2}=0.48, p\right.$ value $\left.<0.001\right)$, and Pearson's correlation coefficient was 0.68 . When considering 12 samples near the land, the regression model showed a very weak relationship and was not statistically significant $\left(R^{2}=0.01, p\right.$ value $\left.=0.74\right)$ and Pearson's correlation coefficient was as low as 0.10 . The different relationships of $\mathrm{OM}$ and SOC detected between samples close to the ocean and far from the ocean were probably due to the natural settings such as inputs of OM, anaerobic environment, and influence of tides.

An average ratio of spatial OM:SOC was $2.01 \pm 0.35$ across the entire study area (Figure 4). Higher ratios were observed in the direction toward the ocean and findings from spatial analysis were compatible with results from our pointbased data. Mangrove soils comprised of organic matter holding $50 \%$ carbon identified a conversion factor of 2 . Even 


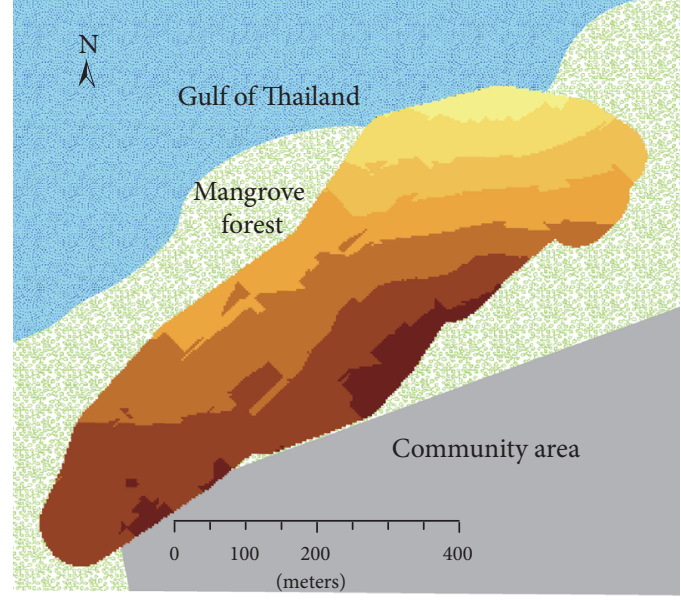

Model type $=$ spherical; range $=945.8 \mathrm{~m}$; partial sill $=2.64$ $\mathrm{ME}=0.06 \%$; lag size $=78.82 \mathrm{~m} ;$ nugget $=3.65$ RMSE $=2.15 \%$; number of lag $=12$

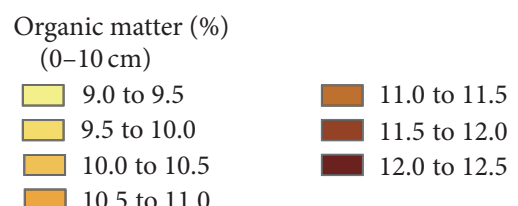

(a)

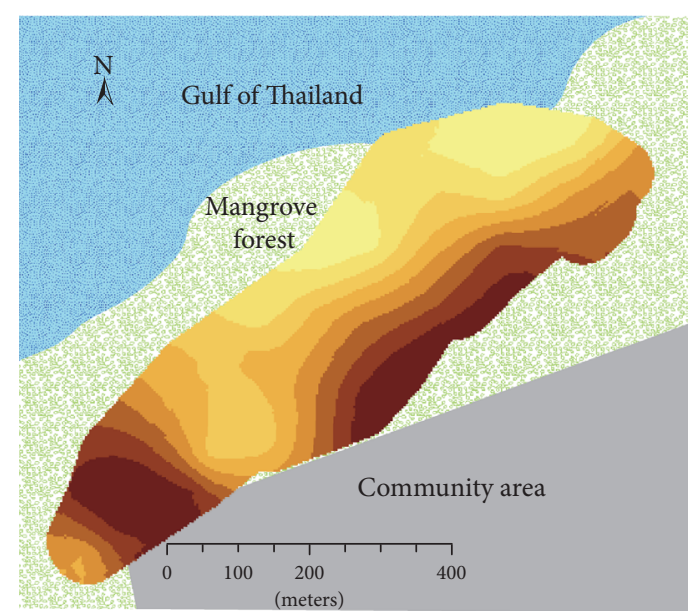

Model type $=$ spherical; range $=322.5 \mathrm{~m}$; partial sill $=3.73$ $\mathrm{ME}=-0.03 \%$; lag size $=40.28 \mathrm{~m}$; nugget $=2.61$

RMSE $=1.95 \%$; number of lag $=12$

Organic carbon (\%) $(0-10 \mathrm{~cm})$

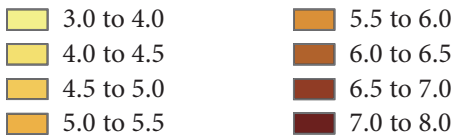

(b)

FIGURE 2: Estimated predictions of (a) soil organic matter content (\%) and (b) soil organic carbon (\%) content based on an ordinary kriging using 29 soil samples. ME is mean error and RMSE is root mean square error.

though the practical use of the 1.724 factor found at the beginning of nineteenth century has been established through authority and has been adopted in many publications, the results from this study were similar to those of other investigators who directly and indirectly indicated the value of 1.724 to be too low to estimate the amount of OM of mangrove and/or wetland soils [15-18].

\section{Discussion and Comparisons}

Looking back at Table 2 we can see that the results were comparatively equal as compared to carbon content under dominance of Rhizophora mangle (mean SOC $2.80+2.70=$ $5.50 \%)$ but were lower when compared to dominance of Avicennia schaueriana (mean SOC $6.10+3.80=9.90 \%$ ) in Brazil (Table 3) [33]. In Indonesia, soils under Avicennia forest and Ceriops forest showed mean \pm SD SOC contents of $3.96 \pm 0.18 \%$ and $11.40 \pm 0.64 \%$ at a depth of $20 \mathrm{~cm}$, respectively. An overview of SOC content studies at different depths and mangrove forests are shown in Table 3.

Of note also is Howard's study [16], where a regression model was expressed across various soil types as OM (\%) = $1.997+1.872 *$ SOC (\%). However, the altered factors and amount of SOC in OM relied on type of soils being from 1.77 to $1.93(51.92-56.39 \%)$ in moors, 1.90 to 1.95 (51.29$52.50 \%)$ in acid peats, $1.92(52.19-52.20 \%)$ in fen peats, $1.81-$ 1.83 (48.36-50.87\%) in alluvial soils, and 1.97-2.07 in mulls. Published results early in the twentieth century showed that 1.8 was a suitable OM-to-SOC factor for the marine sediment
[37]. Later, the simulated model of OM and nutrients in mangrove wetland soils located in the Shark River estuary of south Florida showed OM : SOC ratios from 1.81 to 2.10 with a mean value of 1.98 based on four mangrove sites [38]. Robinson et al. [15], Ponomareva and Plotnikova [39], and Pribyl [18] advocated 2 as the recommended factor for accurate conversion. The SOC-to-OM conversion factor of 2 is, thus, considered to provide better accuracy for estimating the carbon content in mangrove environments or similar types of wetland. Our results coincided with the study from Everglades National Park, Florida [38], in which OM concentrations decreased from $82 \%$ to $30 \%$ in upstream locations down to marine sites.

The recent study mentioned two sources of variability in any estimated factor: first, the different methods used to measure OM and SOC and, second, the diversity in soil composition [18]. In this study, the methods used to estimate $\mathrm{OM}$ and SOC were consistent; thus natural factors played a dominant role. The natural setting of the coastal area can reflect differences in carbon content of OM that, in this study, showed higher conversion factors of SOC to OM in the mangrove environment further from shore. In nature, mixed origins of organic matter in mangrove soil can be very diverse and complex. The near-ocean area showed a high density of mangrove plants that can gain soil OM from fallen detritus decomposition. On the contrary, nearshore areas potentially receive $\mathrm{OM}$ sources from land via human activity as it is closer to the community. Therefore, the rate and source of organic matter input affect microbial 


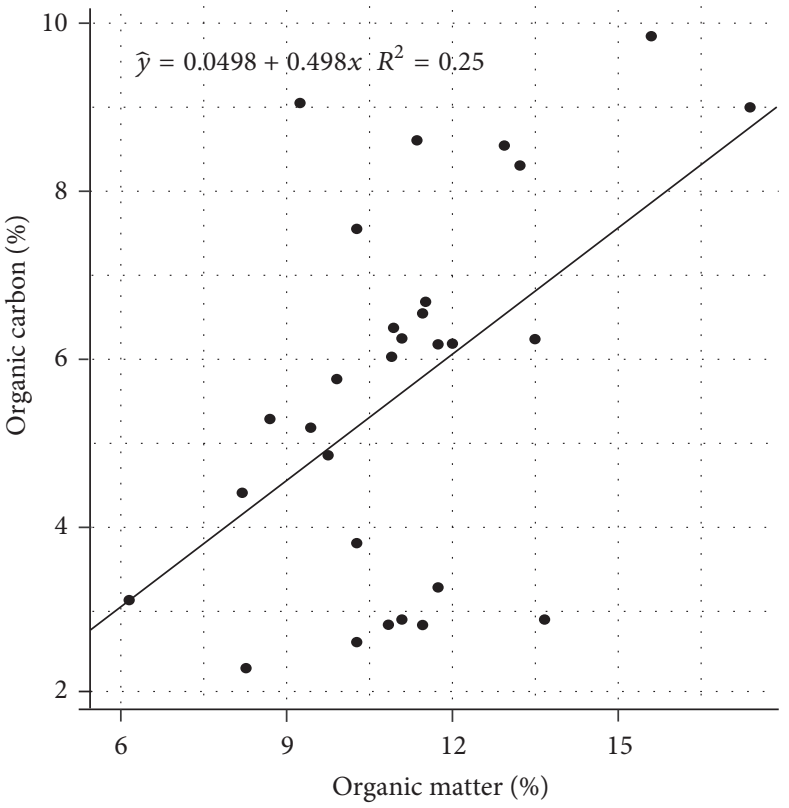

(a)

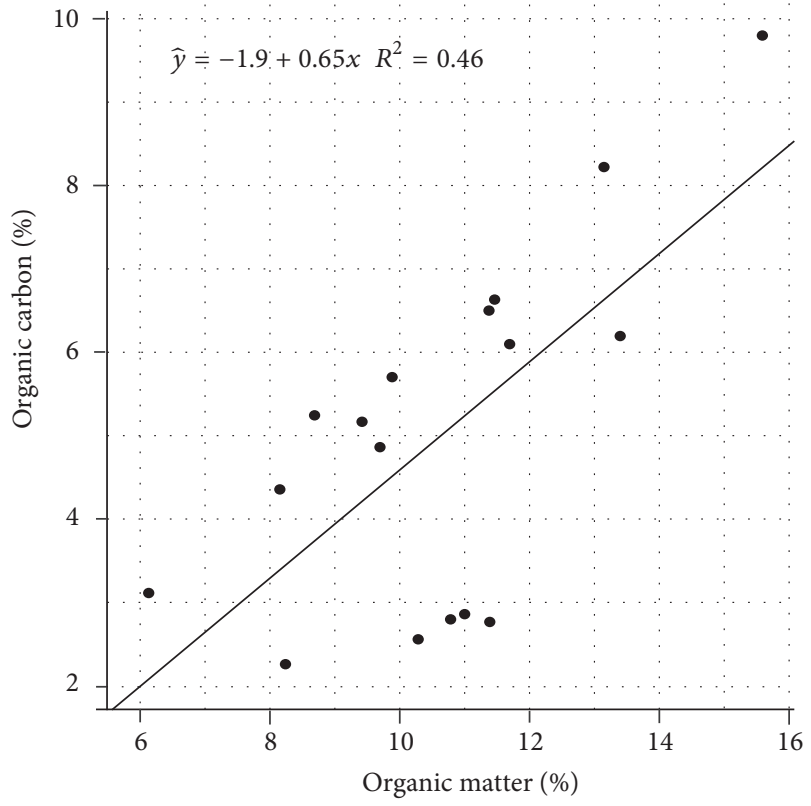

(b)

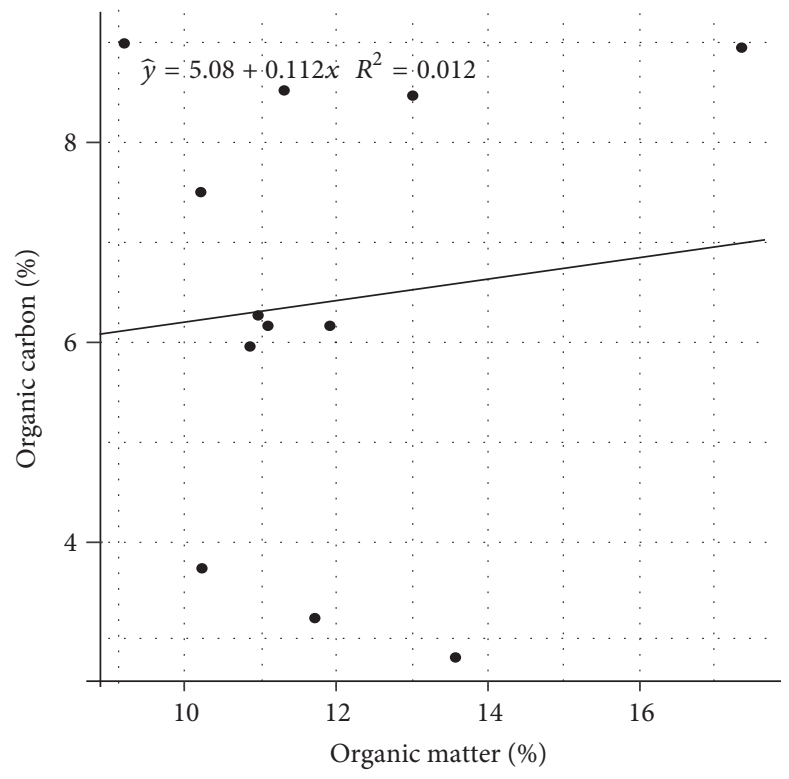

(c)

FIGURE 3: Linear regression of soil organic matter (OM) measured by loss on ignition (LOI) to soil organic carbon (SOC) measured by gas combustion analysis for (a) all soil samples $(n=29)$, (b) soil samples near the ocean $(n=17)$, and (c) soil samples near the land $(n=12)$. The delineation of soil sample groups for (b) and (c) was divided from the center area parallel to the shoreline along the study area.

reactions as well as nutrient availability [40]. Continued production and slow decomposition can lead to very large OM content in soil with long periods of water saturation, but raised OM decomposition occurs in more aerated or less anoxic conditions. However, the speed and ease of carbon mineralization depend on the OM fraction in which it resides; for example, humus-carbon mineralizes slowly when compared to plant residue, particulate OM, and soil microbial biomass [41]. The tidal process is one factor driving a great influx of SOC content and turnover in mangrove forests [42]. Coastal mangroves act as a barrier to any fresh water and tidal flows; this buffer zone often develops suspended matter including OM and SOC in the directions parallel to the coast. Areas further from shore with a high density of mangroves have a vertical mixing of water caused by strong waves and tides which tend to circulate suspended matter; thus OM and SOC usually remain in this zone. Estimates of OM : SOC in soil vary from site to site and may be affected by other factors 
TABLE 3: Overview of available soil carbon content in mangrove forests.

\begin{tabular}{|c|c|c|c|c|c|}
\hline Authors & Place & Site characteristics & Depth & $\begin{array}{l}\text { Reported } \\
\text { statistics }\end{array}$ & $\begin{array}{l}\text { Carbon } \\
\text { content }\end{array}$ \\
\hline \multirow{2}{*}{$\begin{array}{l}\text { Chaikaew and } \\
\text { Chavanich (this study) }\end{array}$} & \multirow{2}{*}{$\begin{array}{l}\text { Upper eastern coast of the } \\
\text { Gulf of Thailand, Thailand }\end{array}$} & \multirow{2}{*}{$\begin{array}{l}\text { Mixed natural and planted mangrove } \\
\text { forests with dominated Avicennia alba } \mathrm{Bl} \text {. }\end{array}$} & $0-5 \mathrm{~cm}$ & $\begin{array}{l}\text { Mean } \pm \\
\text { SD }\end{array}$ & $3.08 \pm 1.25 \%$ \\
\hline & & & $5-10 \mathrm{~cm}$ & $\begin{array}{l}\text { Mean } \pm \\
\quad S D\end{array}$ & $2.51 \pm 1.47 \%$ \\
\hline $\begin{array}{l}\text { Chandra et al. (2015) } \\
\text { [34] }\end{array}$ & Sarawak, Malaysia & Diverse mangrove species & $40 \mathrm{~cm}$ & Range & $1.73-6.24 \%$ \\
\hline \multirow{2}{*}{ Donato et al. (2011) [5] } & \multirow{2}{*}{ Indo-Pacific region } & Oceanic mangrove & $2 \mathrm{~m}$ & Mean & $14.6 \%$ \\
\hline & & Estuarine mangrove & $2 \mathrm{~m}$ & Mean & $7.69 \%$ \\
\hline \multirow[t]{2}{*}{ Ray et al. (2011) [35] } & \multirow[t]{2}{*}{$\begin{array}{l}\text { Northeast coast of the Bay } \\
\text { of Bengal, India }\end{array}$} & $\begin{array}{l}\text { Natural mangrove forest (before } \\
\text { monsoon) }\end{array}$ & $30 \mathrm{~cm}$ & Mean & $0.51 \%$ \\
\hline & & Natural mangrove forest (after monsoon) & $30 \mathrm{~cm}$ & Mean & $0.65 \%$ \\
\hline \multirow{6}{*}{$\begin{array}{l}\text { Lacerda et al. (1995) } \\
\text { [33] }\end{array}$} & \multirow{6}{*}{ Sepetiba Bay, Brazil } & \multirow{3}{*}{ Experimental Rhizophora mangle forest } & $1.5 \mathrm{~cm}$ & Mean & $2.80 \%$ \\
\hline & & & $5-10 \mathrm{~cm}$ & Mean & $2.70 \%$ \\
\hline & & & $10-15 \mathrm{~cm}$ & Mean & $2.70 \%$ \\
\hline & & \multirow{3}{*}{$\begin{array}{c}\text { Experimental Avicennia schaueriana } \\
\text { forest }\end{array}$} & $1.5 \mathrm{~cm}$ & Mean & $6.10 \%$ \\
\hline & & & $5-10 \mathrm{~cm}$ & Mean & $3.80 \%$ \\
\hline & & & $10-15 \mathrm{~cm}$ & Mean & $3.80 \%$ \\
\hline \multirow{2}{*}{ Sukardjo (1994) [36] } & \multirow{2}{*}{ East Kalimantan, Indonesia } & Soils dominated by Avicennia forest & $20 \mathrm{~cm}$ & $\begin{array}{l}\text { Mean } \pm \\
\text { SD }\end{array}$ & $3.96 \pm 0.18 \%$ \\
\hline & & Soils dominated by Ceriops forest & $20 \mathrm{~cm}$ & $\begin{array}{l}\text { Mean } \pm \\
\text { SD }\end{array}$ & $11.40 \pm 0.64 \%$ \\
\hline
\end{tabular}

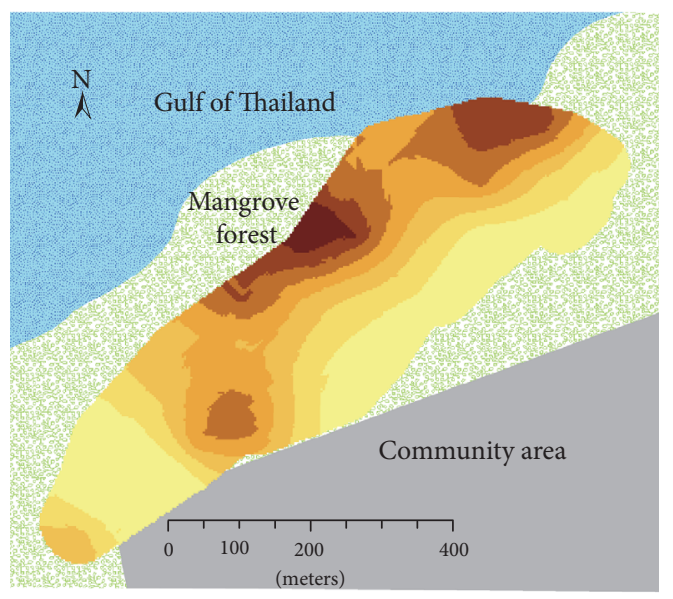

Ratios of organic matter to organic carbon

\begin{tabular}{l|l}
$(0-10 \mathrm{~cm})$ & \\
& 2.4 to 2.6 \\
1.5 to 1.8 & 2.6 to 2.8 \\
1.8 to 2.0 & \\
2.0 to 2.2 & 2.8 to 3.0 \\
2.2 to 2.4 &
\end{tabular}

FIGURE 4: Ratios of soil organic matter obtained by loss on ignition (LOI) and organic carbon measured by gas analyzer based on the ordinary krigged estimated (Figure 2(a) divided by Figure 2(b)).

such as types of vegetation cover, clay in the soil, degree of decomposition, and soil composition, which are out of the study scope.

\section{Conclusions}

The Nature Education Center for Mangrove Conservation and Ecotourism under dominance of mixed natural and planted Avicennia alba Bl. showed a great potential to sequester carbon in soils with high amounts of SOC stored in the top $10 \mathrm{~cm}$. Surface soil $(0-5 \mathrm{~cm})$ contained an average \pm standard deviation in SOC of $3.08 \pm 1.25 \%$ which is greater when compared to subsurface soil $(5-10 \mathrm{~cm})$ with $2.51 \pm 1.47 \%$. Considering the ecosystem in the study area, the origins of the carbon inputs were derived from primary productivity such as leaf debris and plant roots. The spatial variability of $\mathrm{OM}$ and SOC demonstrated the decreasing pattern from land to sea or upper to lower tidal zones. Besides the influence of the tides, we summarized that a substantial load of dissolved and particulate organic matter comes from canals and the community upstream. In terms of the strength of the spatial autocorrelation, the nugget-to-sill ratio of 0.41 for SOC was stronger than 0.58 for OM yet indicated moderate spatial dependency for both variables. Organic matter showed homogenous spatial variability due to the long spatial autocorrelation range. This study contradicts the assumption that has been repeatedly used for more than a century that $\mathrm{OM}$ is $58 \%$ organic carbon and that the conversion factor is 1.724 (van Bemmelen factor). The use of a low factor can cause sequential errors in estimating $\mathrm{OM}$ when multiplying carbon by 1.724 . Organic matter in mangrove soils in this study contained about $50 \%$ organic carbon with the conversion factor of 2. The use of the factor of 2 in different types of wetlands was also recommended by considerable supporting evidence. However, this number is not for universal purposes 
but rather for rough estimation. The conversion factor may vary depending on vegetation cover, temperature, soil type, soil depth, and the technique used to analyze OM and SOC.

\section{Competing Interests}

The authors declare that there is no conflict of interests regarding the publication of this paper.

\section{Acknowledgments}

Funding research was provided by Grants for Development of New Faculty Staff, Ratchadaphiseksomphot Endowment Fund, Chulalongkorn University.

\section{References}

[1] E. Dlugokencky and P. Tans, "Trends in atmospheric carbon dioxide," 2015, http://www.esrl.noaa.gov/gmd/ccgg/trends/.

[2] R. Lal, "Soil carbon sequestration impacts on global climate change and food security," Science, vol. 304, no. 5677, pp. 1623$1627,2004$.

[3] M. Apps, C. Cerri, T. Fujimori et al., Technological and economic potential of options to enhance, maintain, and manage biological carbon reservoirs and geo-engineering, 2001, http://www.grida.no/climate/ipcc_tar/wg3/index.htm.

[4] S. Page, R. Wüst, and C. Banks, "Past and present carbon accumulation and loss in Southeast Asian peatlands," PAGES News, vol. 18, pp. 25-27, 2010.

[5] D. C. Donato, J. B. Kauffman, D. Murdiyarso, S. Kurnianto, M. Stidham, and M. Kanninen, "Mangroves among the most carbon-rich forests in the tropics," Nature Geoscience, vol. 4, no. 5, pp. 293-297, 2011.

[6] C. P. Immirzi, E. Maltby, and R. S. Clymo, "The global status of peatlands and their role in carbon cycling," 1992.

[7] N. Pumijumnong, "Mangrove forests in Thailand," in Mangrove Ecosystems of Asia: Status, Challenges and Management Strategies, I. Faridah-Hanum, A. Latiff, K. R. Hakeem, and M. Ozturk, Eds., p. 470, Springer, New York, NY, USA, 2014.

[8] C. Sprengel, "Ueber Pflanzenhumus, Humussaüre und humussaure Salze," Archiv für die Gesammte Naturlehre, vol. 8, pp. 145220, 1826.

[9] E. Wolff, "Entwurf zur Bodenanalyse," Zeitschrift für Analytische Chemie, vol. 3, no. 1, pp. 85-115, 1864.

[10] G. Loges, "Mittheilungen aus dem agriculturchemischen Laboratorium der Versuchs-Station Kiel: III. Ueber die Bestimmung des Humus in Ackererden," Die Landwirthschaftlichen VersuchsStationen, vol. 28, pp. 229-245, 1883.

[11] F. Schulze, "Anleitung zur Untersuchung der Ackererden auf ihre wichtigsten physikalischen Eigenschaften und Bestandtheile," Journal für Praktische Chemie, vol. 47, no. 1, pp. 241-335, 1849.

[12] W. Detmer, "Mittheilungen aus dem agriculturchemischen laboratorium der Universität Leipzig. VI. Die natürlichen humuskörper des bodens und ihre landwirthschaftliche bedeutung," Die Landwirthschaftlichen Versuchs-Stationen, vol. 14, pp. 248-296, 1871.

[13] F. E. Broadbent, "The soil organic fraction," Advances in Agronomy, vol. 5, pp. 153-183, 1953.

[14] R. A. Gortner, "The organic matter of the soil: 1. Some data on humus, humus carbon and humus nitrogen," Soil Science, vol. 2, no. 5, pp. 395-442, 1916.
[15] G. W. Robinson, W. McLean, and R. Williams, "The determination of organic carbon in soils," The Journal of Agricultural Science, vol. 19, no. 2, pp. 315-324, 1929.

[16] P. J. A. Howard, "The carbon-organic matter factor in various soil types," Oikos, vol. 15, no. 2, pp. 229-236, 1965.

[17] P. J. A. Howard and D. M. Howard, "Use of organic carbon and loss-on-ignition to estimate soil organic matter in different soil types and horizons," Biology and Fertility of Soils, vol. 9, no. 4, pp. 306-310, 1990.

[18] D. W. Pribyl, "A critical review of the conventional SOC to SOM conversion factor," Geoderma, vol. 156, no. 3-4, pp. 75-83, 2010.

[19] B. Murphy, "Key soil functional properties affected by soil organic matter-evidence from published literature," IOP Conference Series: Earth and Environmental Science, vol. 25, Article ID 12008, 2015.

[20] M. V. Lützow, I. Kögel-Knabner, K. Ekschmitt et al., "Stabilization of organic matter in temperate soils: Mechanisms and their relevance under different soil conditions-a review," European Journal of Soil Science, vol. 57, no. 4, pp. 426-445, 2006.

[21] M. C. Peel, B. L. Finlayson, and T. A. McMahon, "Updated world map of the Köppen-Geiger climate classification," Hydrology and Earth System Sciences, vol. 11, no. 5, pp. 1633-1644, 2007.

[22] Google Earth, "Chonburi Province: $13^{\circ} 20^{\prime} 37.05^{\prime \prime} \mathrm{N}$, $100^{\circ} 56^{\prime} 34.83^{\prime \prime}$ E, Eye alt $1.01 \mathrm{~km}$, , 2014, http://www.google.com/ earth/index.html.

[23] G. J. Bouyoucos, "Hydrometer method improved for making particle size analyses of soils," Agronomy Journal, vol. 54, no. 5, pp. 464-465, 1961.

[24] USDA, USDA Textural Soil Classification, 1987, http://www.wcc .nrcs.usda.gov/ftpref/wntsc/H\&H/training/soilsOther/soil-USDAtextural-class.pdf.

[25] M. L. Jackson, Soil Chemical Analysis, Prentice Hall of India, New Delhi, India, 1967.

[26] C. W. Ross, S. Grunwald, and D. B. Myers, "Spatiotemporal modeling of soil organic carbon stocks across a subtropical region," Science of the Total Environment, vol. 461-462, pp. 149157, 2013.

[27] Shimadzu, TOC-V CPH/CPN Total Organic Carbon Analyzer User's Mannual, Corporation Process and Environmental Instrumentation Division, Kyoto, Japan, 2001.

[28] P. Goovaerts, Geostatistics for Natural Resources Evaluation, Oxford University Press, New York, NY, USA, 1997.

[29] J. S. Levinton, Marine Biology: Function, Biodiversity, Ecology, Oxford University Press, New York, NY, USA, 1995.

[30] A. A. Berhe, J. Harte, J. W. Harden, and M. S. Torn, "The significance of the erosion-induced terrestrial carbon sink," BioScience, vol. 57, no. 4, pp. 337-346, 2007.

[31] P. D. Howe, E. M. Markowitz, T. M. Lee, C.-Y. Ko, and A. Leiserowitz, "Global perceptions of local temperature change," Nature Climate Change, vol. 3, no. 4, pp. 352-356, 2013.

[32] J. A. Bird and M. S. Torn, "Fine roots vs. needles: a comparison of $13 \mathrm{C}$ and $15 \mathrm{~N}$ dynamics in a ponderosa pine forest soil," Biogeochemistry, vol. 79, no. 3, pp. 361-382, 2006.

[33] L. D. Lacerda, V. Ittekkot, and S. R. Patchineelam, "Biogeochemistry of mangrove soil organic matter: a comparison between Rhizophora and Avicennia soils in South-Eastern Brazil," Estuarine, Coastal and Shelf Science, vol. 40, no. 6, pp. 713-720, 1995.

[34] I. A. Chandra, G. Seca, R. Noraini et al., "Soil carbon storage in dominant species of Mangrove Forest of Sarawak, Malaysia," International Journal of Physical Sciences, vol. 10, no. 6, pp. 210214, 2015. 
[35] R. Ray, D. Ganguly, C. Chowdhury et al., "Carbon sequestration and annual increase of carbon stock in a mangrove forest," Atmospheric Environment, vol. 45, no. 28, pp. 5016-5024, 2011.

[36] S. Sukardjo, "Soils in the mangrove forests of the Apar nature reserve, Tanah Grogot, East Kalimantan, Indonesia," Southeast Asian Studies (Kyoto), vol. 32, no. 3, pp. 385-398, 1994.

[37] P. D. Trask, "Organic content of recent marine sediments," in Recent Marine Sediments, P. D. Trask, Ed., pp. 428-453, Dover Publications, New York, NY, USA, 1938, http://archives.datapages.com/data/sepm_sp/SP4/Organic_Content_of_Recent.htm.

[38] R. Chen and R. R. Twilley, "A simulation model of organic matter and nutrient accumulation in mangrove wetland soils," Biogeochemistry, vol. 44, no. 1, pp. 93-118, 1999.

[39] V. V. Ponomareva and T. A. Plotnikova, "Data on the degree of intramolecular oxidation of humus in various soil groups (problem of the carbon to humus conversion factor)," Soviet Soil Science, vol. 7, pp. 924-933, 1967.

[40] D. E. Canfield, E. Kristensen, and B. Thamdrup, "Aquatic geomicrobiology," in Advances in Marine Biology, vol. 48, pp. 517-599, Elsevier, Amsterdam, Netherlands, 2005.

[41] NRCS, Soil Quality Indicators, 2009, https://www.nrcs.usda .gov/Internet/FSE_DOCUMENTS/nrcs143_019177.pdf.

[42] J. P. Zhang, W. X. Yi, C. D. Shen et al., "Quantification of sedimentary organic carbon storage and turnover of tidal mangrove stands in southern China based on carbon isotopic measurements," Radiocarbon, vol. 55, no. 2-3, pp. 1665-1674, 2013. 

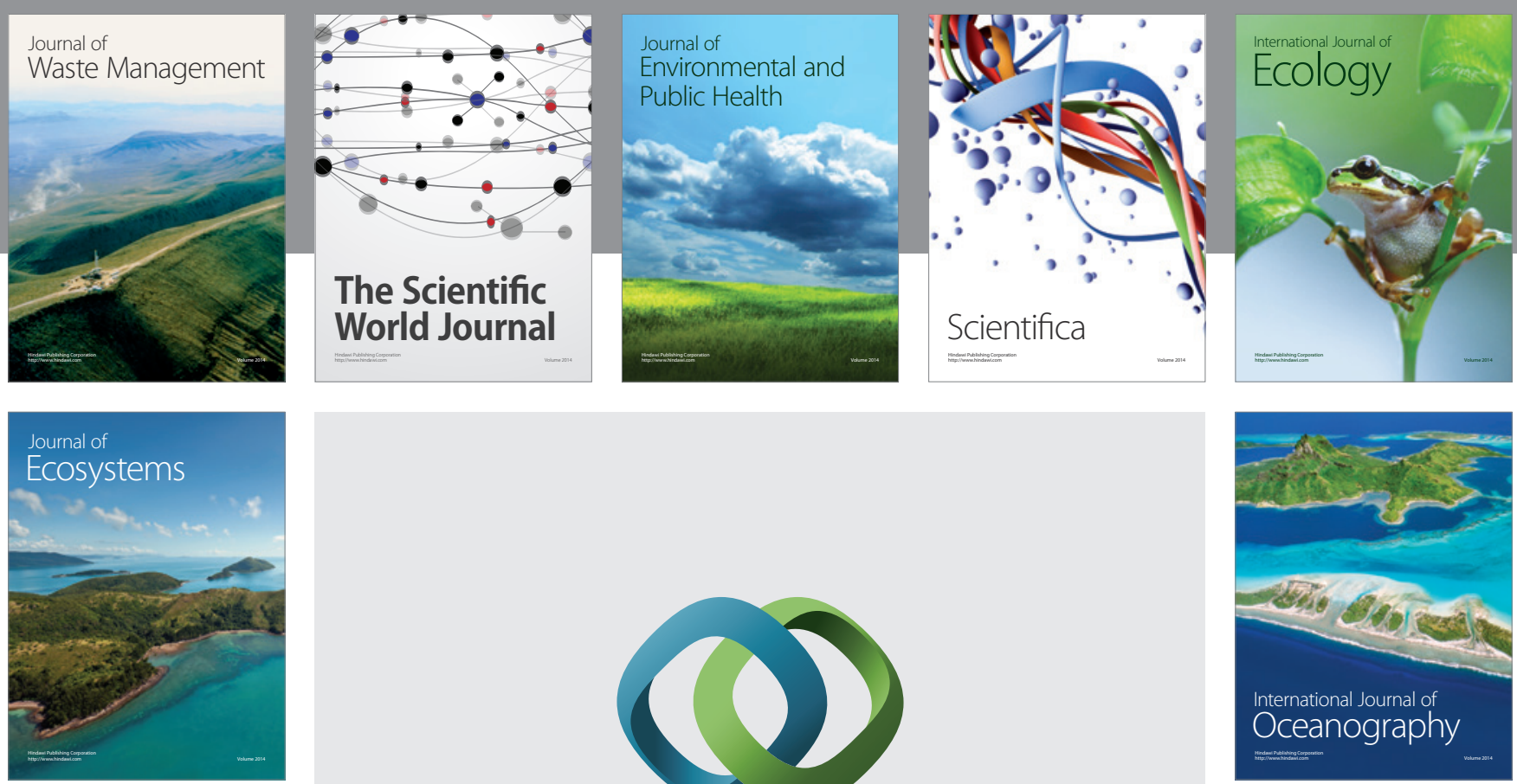

The Scientific World Journal
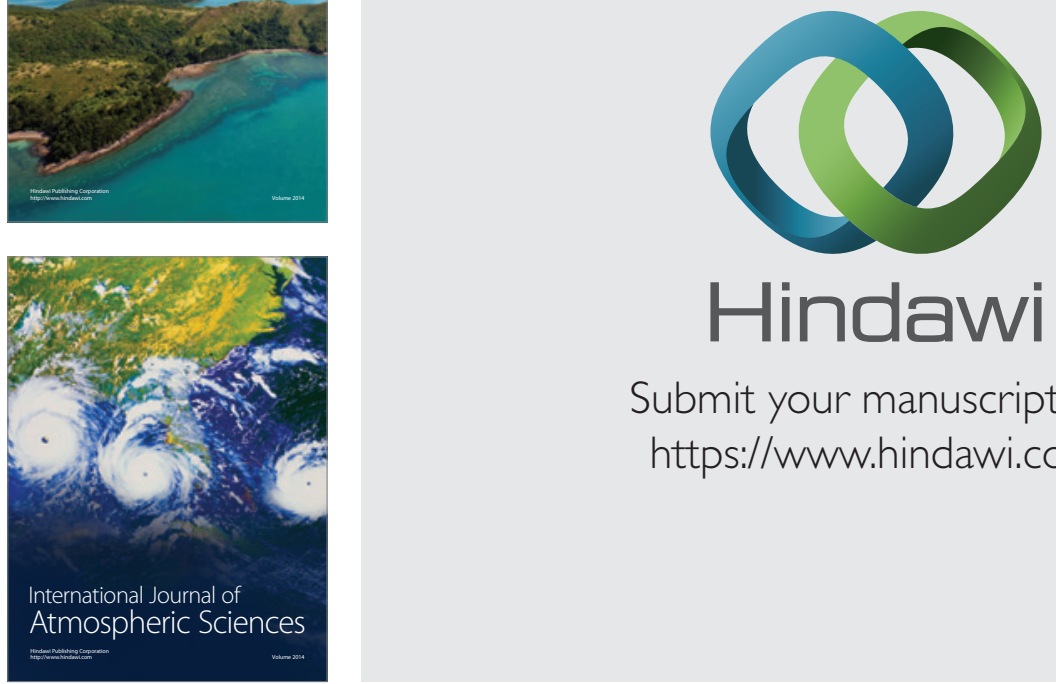

Submit your manuscripts at

https://www.hindawi.com
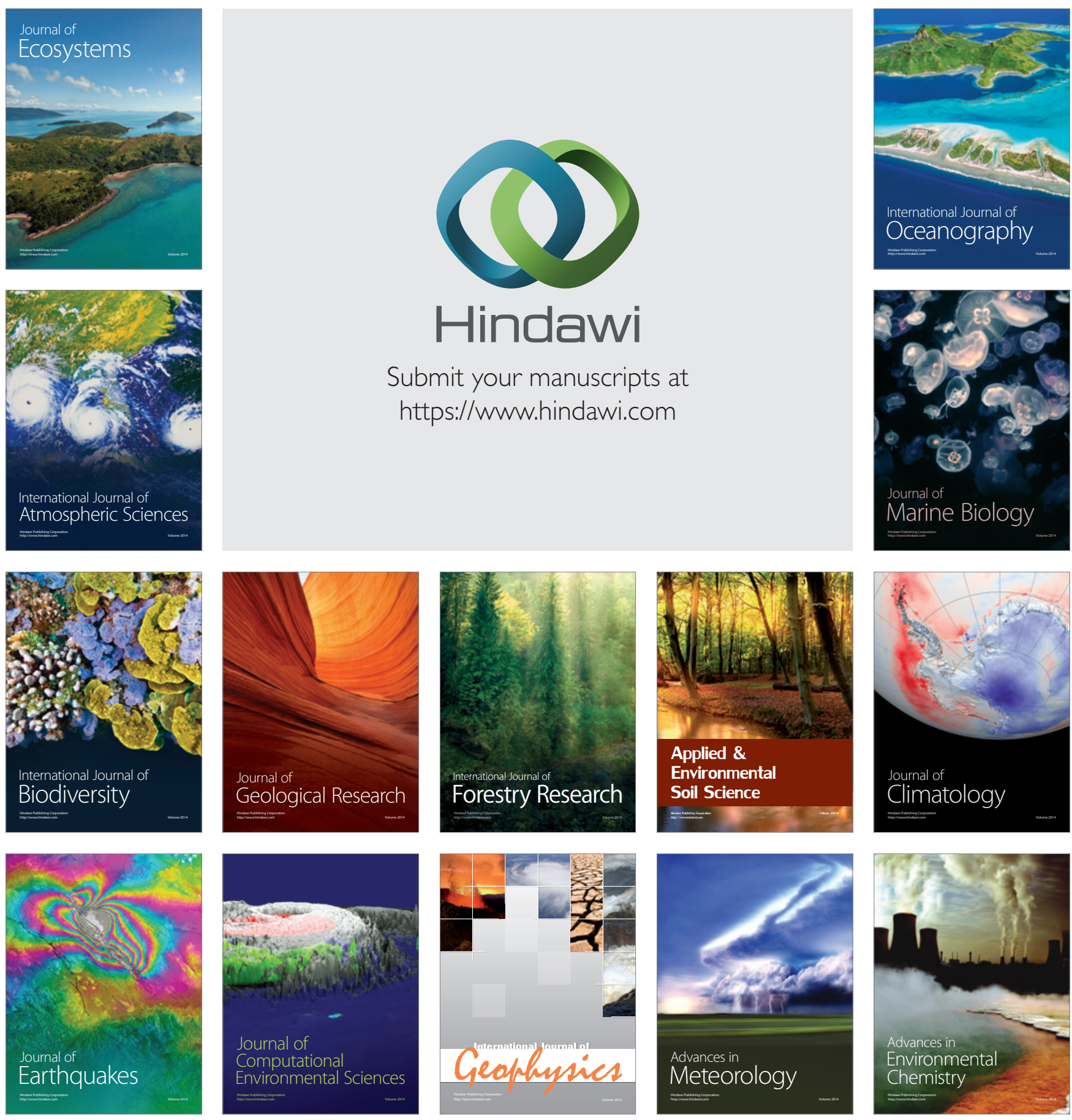